Journal of Applied Veterinary Sciences, 6 (3): 38 -47 (July 2021).

ISSN: Online: 2090-3308, Print: 1687-4072

Journal homepage : https://javs.journals.ekb.eg

\title{
Pathological Impact of Johne's disease in Cattle: A Review Article
}

\section{S.A. Radam $^{1 *}$; I.B. Falih ${ }^{1}$; S.L. Hassan ${ }^{1}$; H.B. AL-Sabaawy ${ }^{2}$}

${ }^{1}$ Department of pathology and poultry disease, Collage of Veterinary Medicine, University of Baghdad, Iraq.

${ }^{2}$ Department of pathology and poultry disease, Collage of Veterinary Medicine, University of Mousl, Iraq.

*Corresponding Author, S.A. Radam; E-Mail: suraradam@covm.uobaghdad.edu.iq

\section{ABSTRACT}

Johne's disease is an international healthiness problem affecting ruminants. It is caused by Myobacterium avium spp. paratuberculosis (MAP). It has serious production-limiting important and also caused significant cost-effective loss in flocks due to direct impact on delayed/reduced breeding, infertility, culling, mortality, and milk reduction. This disease is problematic to diagnose because of elongated incubation times. Proof of identity this disease subclinical can shed the organism as a source of infection for other herds; so, it is critical for control. The present study deals with the morphological (grossly, histopathologically and histochemically) characterization of the disease in cattle. The corpse appears hidebound with sunken eyes and with persistent and non- responsive diarrhea. The necropsy of visceral showed gelatinization and outlying fat. Grossly chiefly pathological alterations in digestive tract such as severe congested of small intestine with marked thickening of its wall a combined with enlargement of mesenteric lymph nodes and gallbladder appear distension with severe thickening walls and blood mixed with bile. Histopathological examinations revealed severe infiltrations of inflammatory cells such as macrophages, lymphocytes, and epithelioid cells with multiple langhans giant cells in bowel layers and mesenteric lymph nodes with diffuse lepromatous reaction were observed in these lymph nodes and other organs like liver, tonsils and kidney.
\end{abstract}

Review Article:

DOI:

https://dx.doi.org/10.21608/javs.2021 $\underline{.76316 .1080}$

Received :15 May, 2021.

Accepted :22 June, 2021.

Published in July, 2021.

This is an open access article under the term of the Creative Commons Attribution 4.0 (CC BY) International License . To view a copy of this license, visit:

http://creativecommons.org/licenses/by/4.0/

Keywords: Cattle, Giant cells, Granuloma, Johne's disease, Paratuberculosis.

J. Appl. Vet. Sci., 6(3): $38-47$.

\section{INTRODUCTION}

Paratuberculosis is long-lasting emaciating disease characterized by granuloma in gut, lymphangitis, and lymphadenitis of regional L.N. It is an important infectious disease of domestic and wild ruminants worldwide caused severe commercial losses of ruminants characterized by alternating diarrhea at first and come to be more persistent and severe above (7) days or months lacking blood, mucus, epithelial debris, and wasting, limited weightiness loss (Roy $\boldsymbol{e t}$ al., 2017), reduced milk secretion, increased counter of somatic cell, mastitis, reduced fertility (Elzo et al., 2009), roughening of hair coat, anemia with usual body temperature and food desire and when advanced affected animals become gaunt then die with terminal cachexia and dehydration (McAloon, et al., 2016). This disease have length incubation period ranged from 2-5 years, communal in cattle and not often exposed theoretical symbols before 2 years old infrequently cases (Windsor et al., 2010).

\section{Etiology:}

Mycobacterium paratuberculosis (Map) an importance pathogen caused a chronic, progressing granulomatous enteritis. It's an aerobal, non-spore formation, Gram+, non-motile, acid-fast bacilli with slowing growth intracellular parasite (Karen Stevenson et al., 2015). It is correlated with $M$ avium and wood pigeon bacillus $M$ silvaticum, firstly sequestered of MAP by German Johne and Frothingham in 1895, Its infested ruminants \& non-ruminants (cattle, sheep, goats, deer, etc.) (Grewal et al., 2016).

MAP strains have been shared into at least two groups, Type II strains (type C) initially identification in cattle, but also wide host range including sheep, goats, camelids (Stevenson et al., 2002), Type I (type S) strains mostly establish in small ruminants and other species such as cervids, camelids, camels, several cattle nearby connection with sheep (Whittington et al., 2001). 


\section{Clinical Signs:}

Johne's disease Clinically characterized by pattern of chronic and enlightened emaciation with diarrhea, green feces, bubbly and without blood or mucus and its consistency .It expands for tiny times then diarrhea coming back with greater than before severity. The affected animals are sunny, alert and consume good during the course of disease progress while progressive state saw edematous fluid in submandibular, rectal thickened or corrugated mucosa may feel. Clinical signs of JD do not seem up to animals aged extra than $3-4$ years and some herds onset disease in 2-year-old (Ashwani Tiwari et al., 2006).

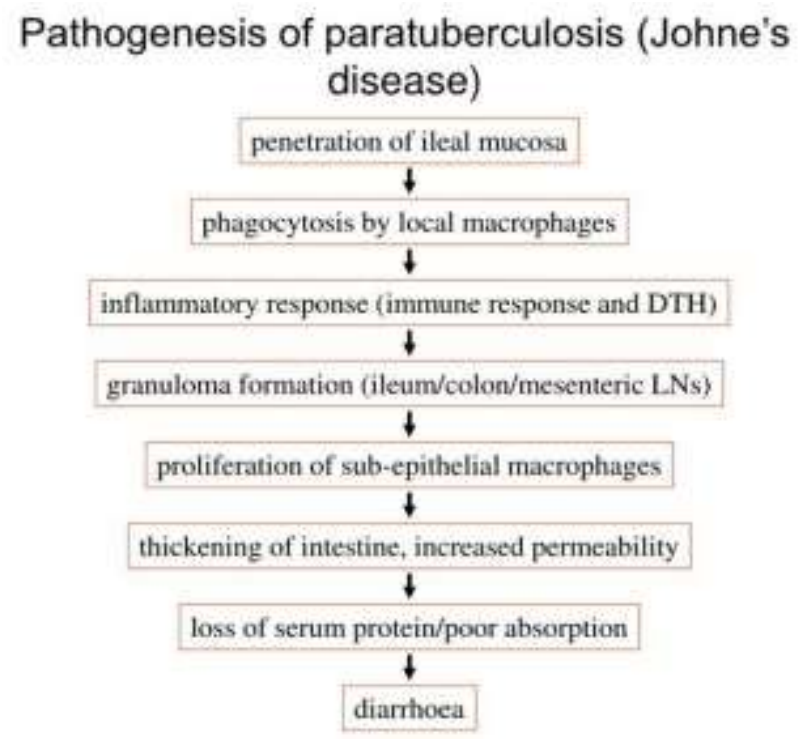

Johne's disease causes a long-lasting diarrhea characterized by absorption deficiency which leads to starvation and damage of muscle. Infant animals are infested primarily via the fecal-oral when ingesting MAP attached to intestinal mucosa facilitated by M-cells and enterocytes (Bermudez et al., 2010) forming close-fitting junctions in intestinal mucosa to amplify permeably (Bannantine et al., 2013). MAP oxidoreductase (AlonsoHearn et al., 2008), fibronectin-binding protein (Secott et al.,2002) and the histone HupB (Lefrancois et al., 2011) have chief role MAP adhesion epithelial cell and/or invasive. largely bovine blood-monocyte-derived macrophages (BMDM) due to capacity of organism to avert macrophage stimulation, blocking acidification and maturation of phagosome, attenuate appearance of Ags to the immune system with excessive IL-10 expression from epithelial cells as one of the mechanisms by which MAP organisms suppress inflammatory, immune, and antimicrobial responses and promote their survival within host mononuclear phagocytesin macrophage recruitment and transepithelial migration (Lamont et al., 2012).
Bacillus are phagocytosed by sub- and intraepithelial macrophages (Lugton et al., 1999). MAP ability to survival and replication within phagocytic cells acting as strategic in pathogenesis ( Zhao et al., 1997). Usage of a cultured route ideal show MAP lipid conformation transformed development of macrophages and phenotype of pro-inflammatory (Everman, 2015), typical granulomatous enteritis as host cellular immune response (Govardhan Rathnaiah et al., 2008), described by thicken and grooved in intestine barrier (Figure 1B) and lymph nodes (Figure 2C). Tissue macrophages and dendritic cells have starring role in PAMP reorganization via toll-like receptors (EI Chamy et al., 2008).

Organizer of MAP infections be influenced by Th1 response and macrophages activated by (INF- $\gamma$ ) secreted by Th1 T lymphocytes (Stabel J.R., 2000), phagocytic cells make active \&killing by nitric oxide(NO) which induced synthase established in cattle (Li et al., 2011). MAP affects macrophages function by exclusive mRNA expression profiles (Tooker $\boldsymbol{e t}$ al., 2002), declined of apoptosis and antigen presentation (Coussens et al., 2012), and cytokine that indicative significanly(Weiss et al., 2001). MAP drives $T$ helper cells and attractive IL-4, IL-5, IL-10, and inhibition of tissue conversion elements (Coussens et al., 2005).

\section{Gross And Histopathological Finding:}

The infected animals appear thin or emaciated with advanced disease, independent edema and/or fluid in holes, grossly intestinal changed characterized by severe congested and marked thickening of its wall mostly appearance in distal small intestine while advanced cases extended from jejunum to colon with separate plaques presented in the disease at early also mesenteric lymph nodes enlargement (Figures 1 \& 2) and gallbladder appear distension with severe thickened walls and blood mixed with bile (Gulliver et al., 2015).

Histopathological lesion in cattle characterized by acid-fast bacilli readily detectible in both intracellularly and extracellularly with diffuse cellular infiltration of the lamina propria (Gonzalez et al., 2005), combined with lymphocytes, plasma cells, eosinophils with occasional epithelioid cells and langhans' giant cells in tips or bases of the villi with disappearance of necrosis, hyperaemia or fibrosis these changes manifest in the submucosa friendship with lymphoid tissue, rise numeral of epithelioid cells and cell accumulated compress and obliterated the crypts contributed to thickened of digestive system as shown in Fig.3 (Gonzalez J et al., 2005). 


\section{Pathological Impact of Johne's disease in Cattle}
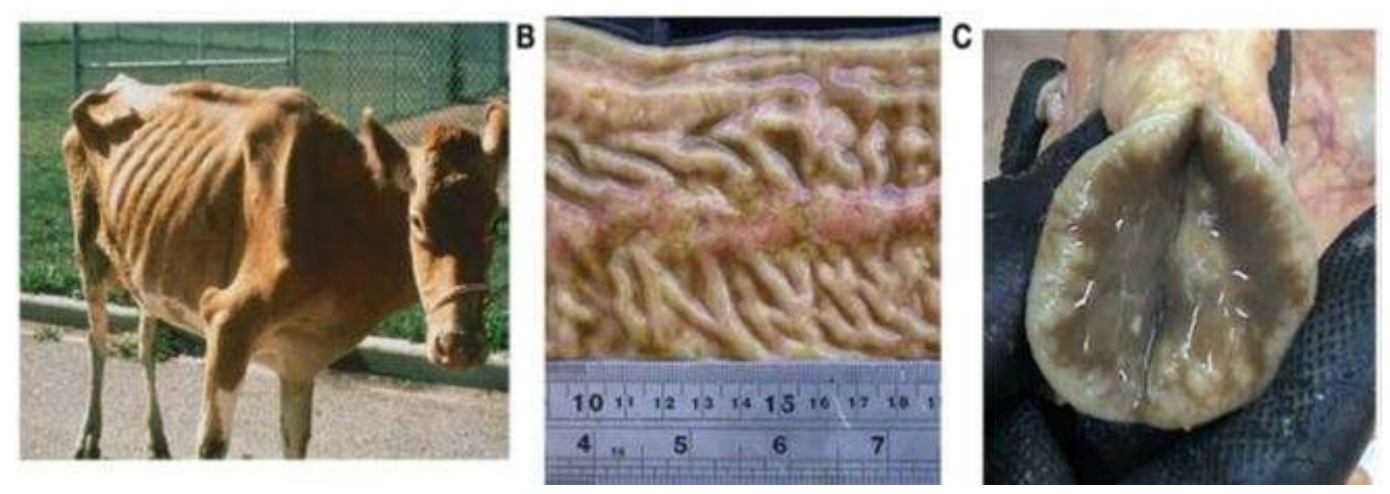

Fig. 1: (A) Severe weakened cow a combined with chronic diarrhea, malabsorption, muscular wasting, and malnutrition. (B) thickening of intestinal mucosa with projecting Peyer's patches (C) lymph node showed as white spots. Of hyperactive lymphoid tissue.

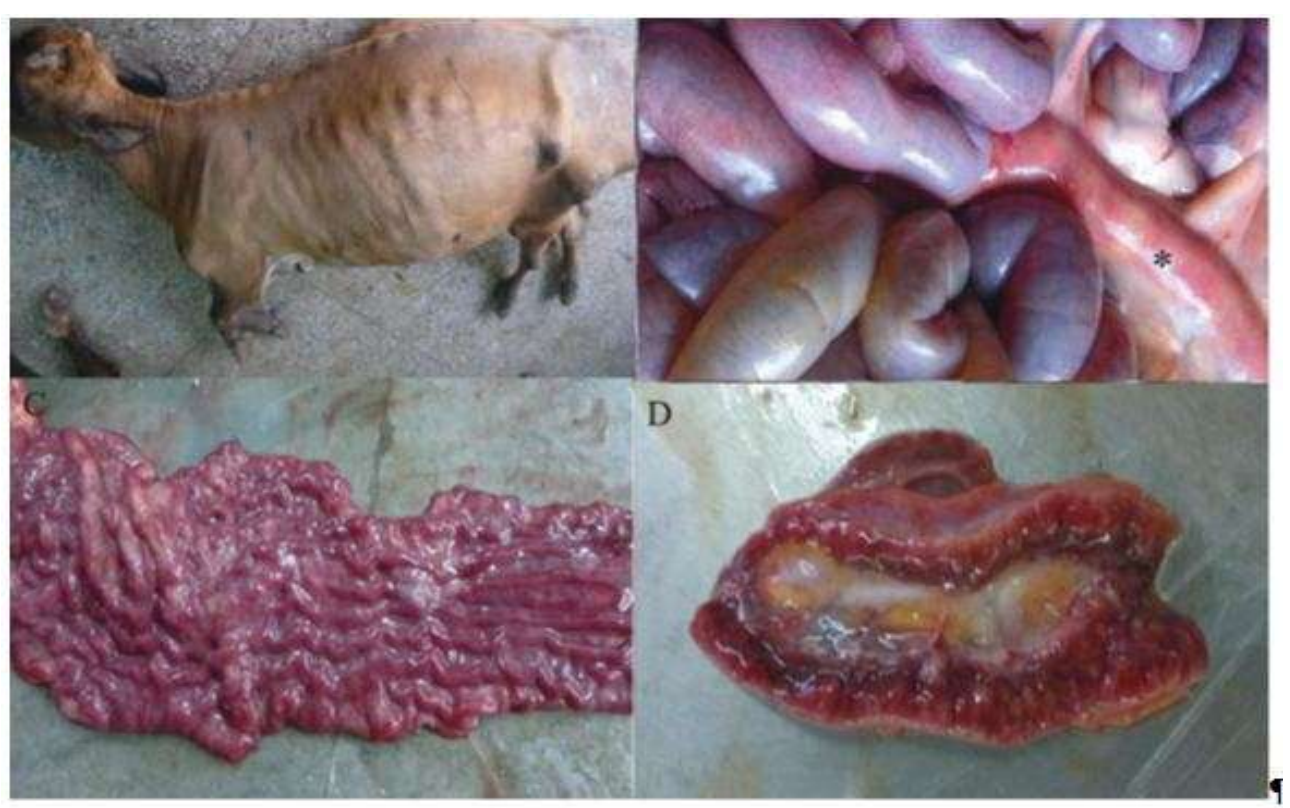

Fig. 2: Macroscopical changes in cattle affected by JD show hidebound condition (A); severe congestion in serosal capillaries of small intestine along with cording of mesenteric lymph nodes (B) marked thickening of the intestinal wall with typical longitudinal corrugations $(\mathrm{C})$; multinodular appearance in mesenteric lymph node (D).

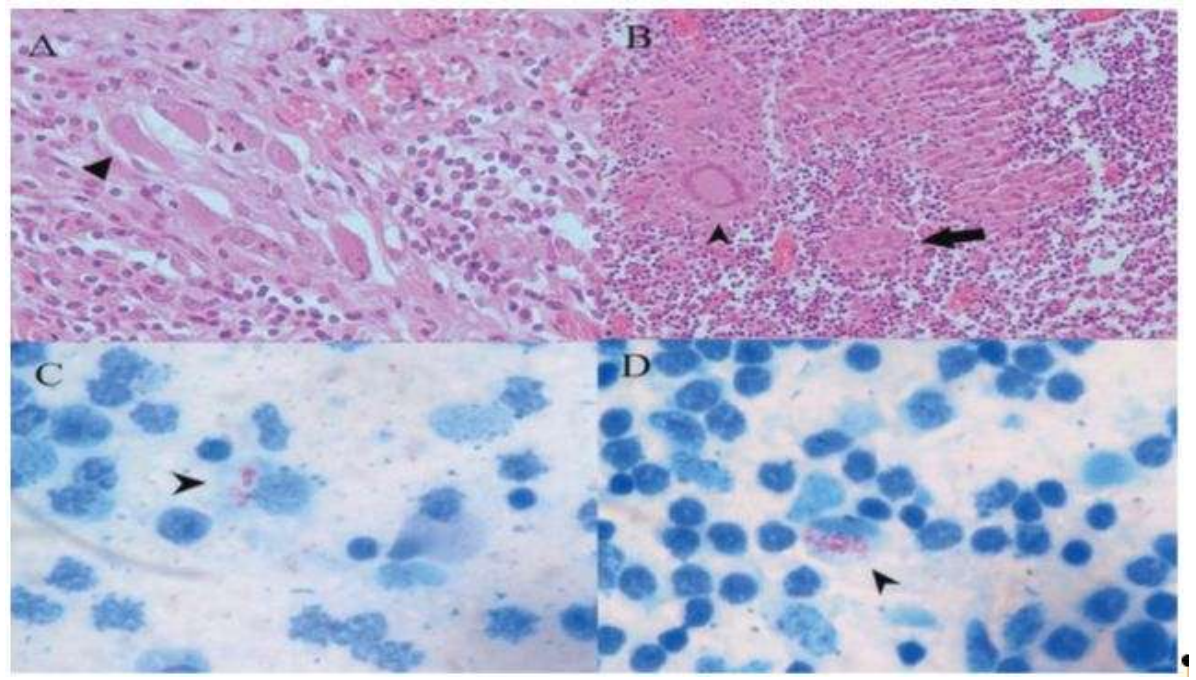

Fig. 3: Histopathological changes in the intestine and mesenteric lymph node of cattle infected by JD. Show (A) accumulation of epithelioid cells in lamina propria of small intestine (B) microgranuloma formation with langhans giant cells infiltrated in mesenteric LN.parenchyma (C) multiple AFB in the cytoplasm of macrophages in impression smear prepared from the small intestine (D) mesenteric lymph nodes. 


\section{S.A. Radam et al...........}

Histopathological results of mesenteric and other regional LNs such as ileocecal enlargement and edematous with revealed multifocal lepromatous granuloma (epithelioid and giant cells in the paracortical areas with necrosis) that exchanged the cortex and medullary sinuses. he infected lymphatic vessels are bounded by lymphocytes and plasma cells and clusters of epithelioid cells in the lumen resulting in epithelioid granulomas which formed in wall then projected to lumen with improved records of real body macrophages full with cellular and karyorrhectic debris of apoptotic lymphocytes because the macrophages infested with mycobacteria have affinity to actuate apoptotic pathways, resultant in cell death (Koul $\boldsymbol{e t}$ al., 2004). Pathological straining induce lesser levels of apoptosis comparative to minus pathogenical strains (Weiss et al., 2008). Also, it can labeled focal granulomas in liver, tonsil, other lymph nodes and frequently in kidney and lungs. liver histopathological examination showed overfilled of capillaries, portal vein, and hepatic vein in center of lobules, granulomatous \&mononuclear cells infiltrate in portal tracts and trabeculae as shown in Figures 4, 5, and 6 ( Del-Pozo. et al., 2013).
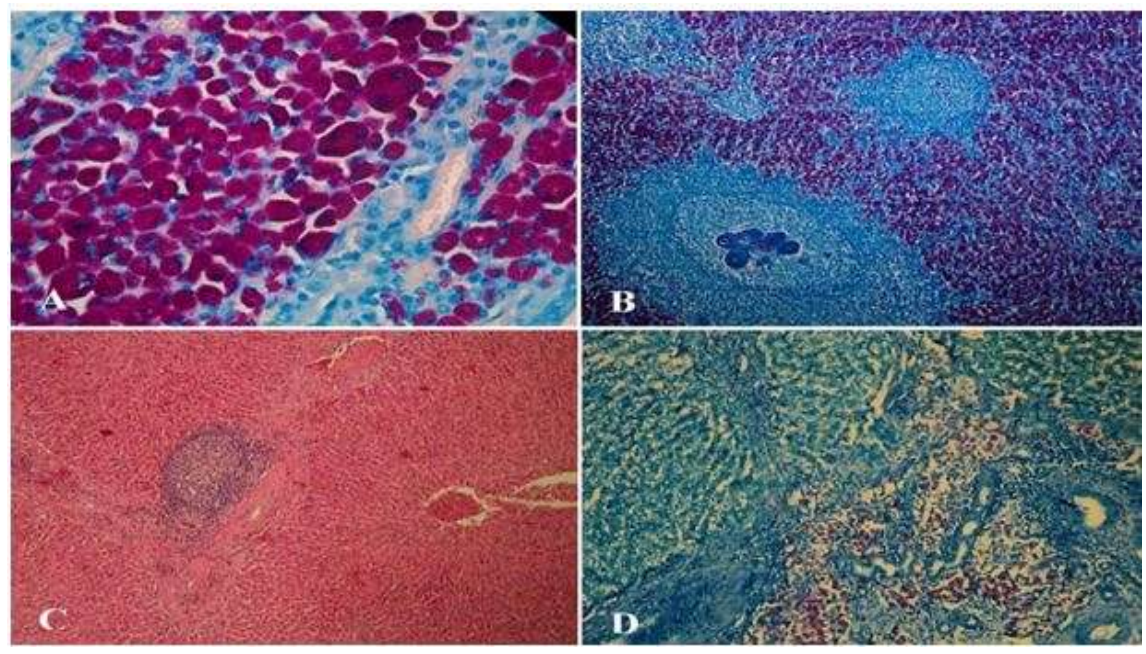

Fig. 4: (A) Ileum, acid-fast bacilli (AFB) engulfed by macrophages of lamina propria . (B) Mesenteric lymph node, necrotic granuloma \&calcification with AFB in the cortex and laminar (C) Liver, granulomatous in portal area (D) Liver, present red color of AFB engulfed by macrophages in a portal area.
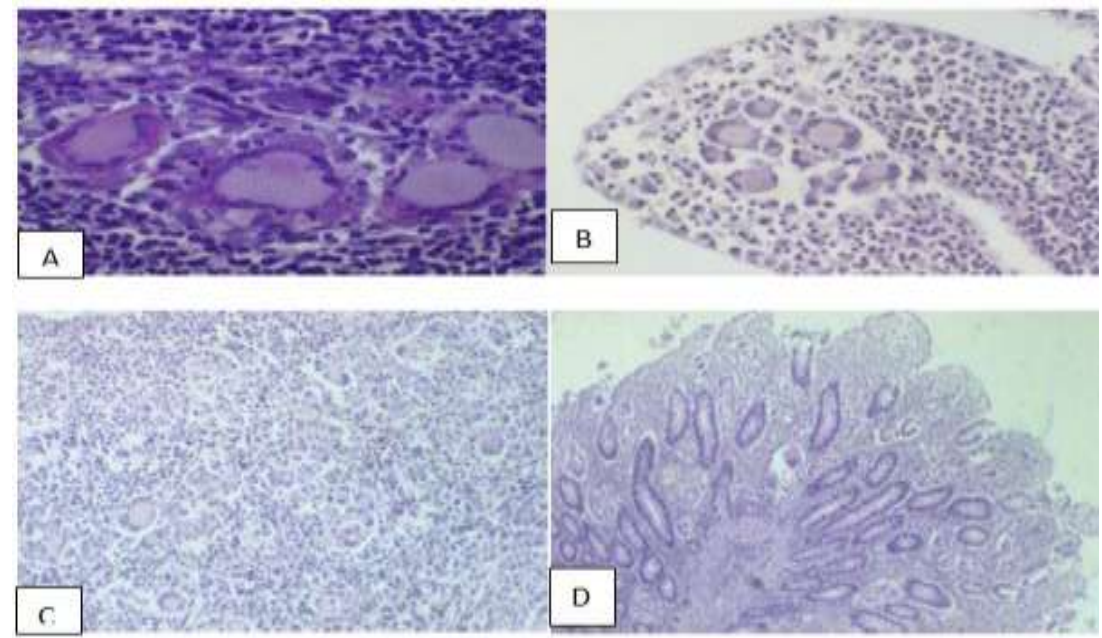

Fig.5 (A) Focal granulomatous lesion formed by aggregation of macrophages and Langhans giant cells in distal jejunal lymph node interfollicular area(B) Multifocal granuloma in intestinal villus apex caused focal thickening of mucosa C) Severe and diffuse multibacillary lesion in distal jejunal lymph node a combined with diffuse granulomatous lymphadenitis with macrophages and Langhans giant cells infiltration, (D) Diffuse multibacillary in distal jejunum infiltrated by macrophages correlated to fused of villi and thickening of mucosa. 


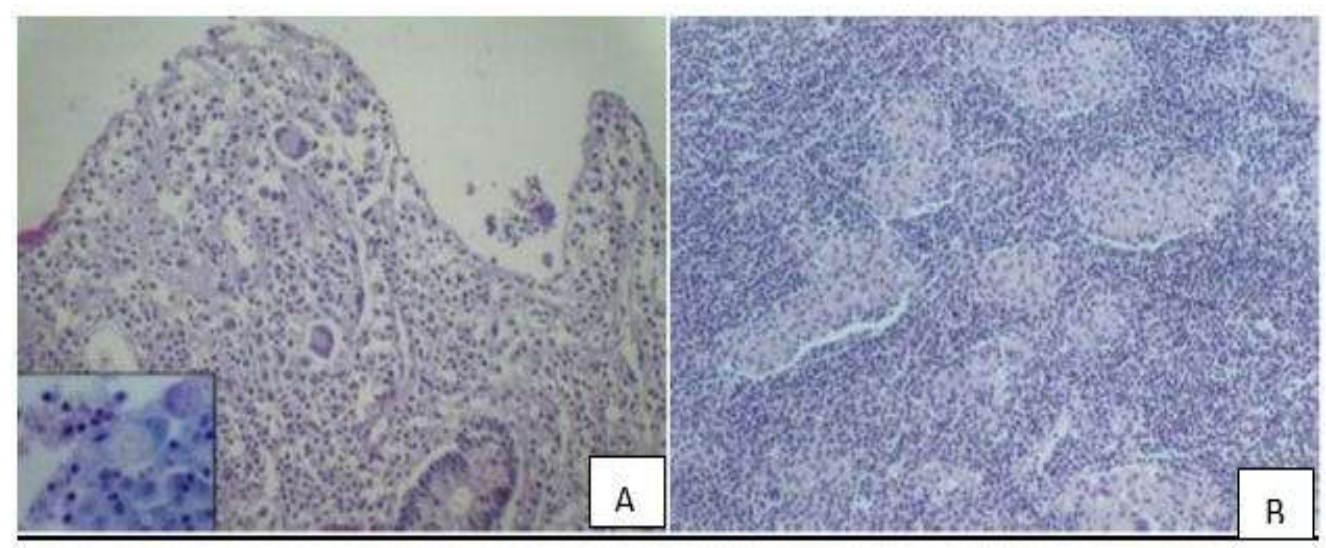

Fig. 6: (A) Diffuse intermediate lesion in ileocaecal valve with infiltration of macrophages, lymphocytes and Langhans giant cells which contain small amounts of mycobacteria causing short and thicked of the villi. (B) Severe diffused granulomatous lymphadenitis in distal jejunal LN .

\section{Diagnosis:}

Several methods used for diagnosis of subclinical/clinical cases of Paratuberculosis to categorize infected animals can vary based on the disease stage such as:

1) Histopathological section can be helpful in diagnosis the clinical cases diagnostic by histopathological and histochemical characteristic lesions from infected animals may serve as a costeffective and specific technique for JD's diagnosis while subclinical cases other tests may be employed to complement histological diagnosis because it exhibit low-grade lesions with lower numbers of bacteria and may be difficult to diagnose with histopathology, a positive diagnosis of lesions indicated by present one or more giant cells and/or aggregation of three epithelioid macrophages which spot in the intestinal lamina propria and/or lymph node cortex with company of acid-fast bacillus of $M$ Paratuberculosis (Whitlock et al., 1996).

2) Ziehl-Neelsen Stain used to detected clinical cases of JD when the MAP appear as clomps of small, strongly acid-fast bacilli in feces, intestinal mucosa or cutting of lymph node surface (Coelho et al., 2010).

3) Immunostaining methods can identify bacteria in tissue samples but ABs may cross-react with other mycobacteria these methods used by taken biopsies of ileum and regional lymph nodes, M. avium ssp. paratuberculosis may cultivate on sum of specific culture media (Berghaus et al., 2006).

4) PCR assays are quite molecular techniques sensitive and rapid for diagnosis of JD $M$ paratuberculosis recognized from colonies or liquid cultured medium target insert sequence IS 900 and ISMAP02 of $M$ paratuberculosis follow by limitation enzyme which analyzed PCR production (Donat $\boldsymbol{e} t$ al., 2016 and Nadine A. El-Sebay et al., 2021).
5. Serology used for documentation of infection like ELISAs Which is more sensitive and detected subclinically in infected cattle also antibodies in milk, complement fixation and agar gel immunodiffusion tests, CFT and AGID also used in clinical cases (Weber et al., 2009); the insensitive and nonspecific intradermal testing are common and purified protein derived tuberculin can detected DTH to MAP. The gamma interferon assay in vitro can recognize some subclinically septic case, Cross-reactivity with others lead to false positive reactions in both tests (Kalis et al., 2003).

\section{Different Diagnosis:}

Johne's disease possible differential diagnostic in cattle from chronic fascioliasis, gastro-intestinal parasitism, enzootic bovine leucosis, mucosal disease, copper deficiency, left displacement of the abomasum, lipomatosis (fat necrosis), tumours of the gastro-intestinal tract, salmonellosis, coccidiosis, carbohydrate engorgement, yersiniosis.

\section{Difference between Tuberculosis, Paratuberculosis and Pseudotuberculosis:}

The TB is chronic disease causative by Mycopacterium bovis and formed granuloma typical characterestic by necrotic center which is amorphous caseated granular fragments with loss of cellular feature also acid-fast bacilli are present, these necrotic area circled by epithelioid cells, lymphocytes, histiocytes, fibroblasts and Langhans' giant cells (Domingo et al.,2014) while paratuberculosis diffused lepramatous and Corynebacterium pseudotuberculosis is a Gram+ and small bacillus, It is the causative agent of Caseous Lymphadenitis (CLA) in goats and sheep, while in cattle caused a disease identified as Oedematose Skin Disease (OSD) (Tejedor et al., 2008 and Nasr et al., 2019), pseudotuberculosis characterized by ulcerative granulomatous seemed in three clinical forms: cutaneous, mastitic and visceral and can observed mixed forms as shown in Fig.7 (Almeida et al., 2017). 


\section{S.A. Radam et al..........}
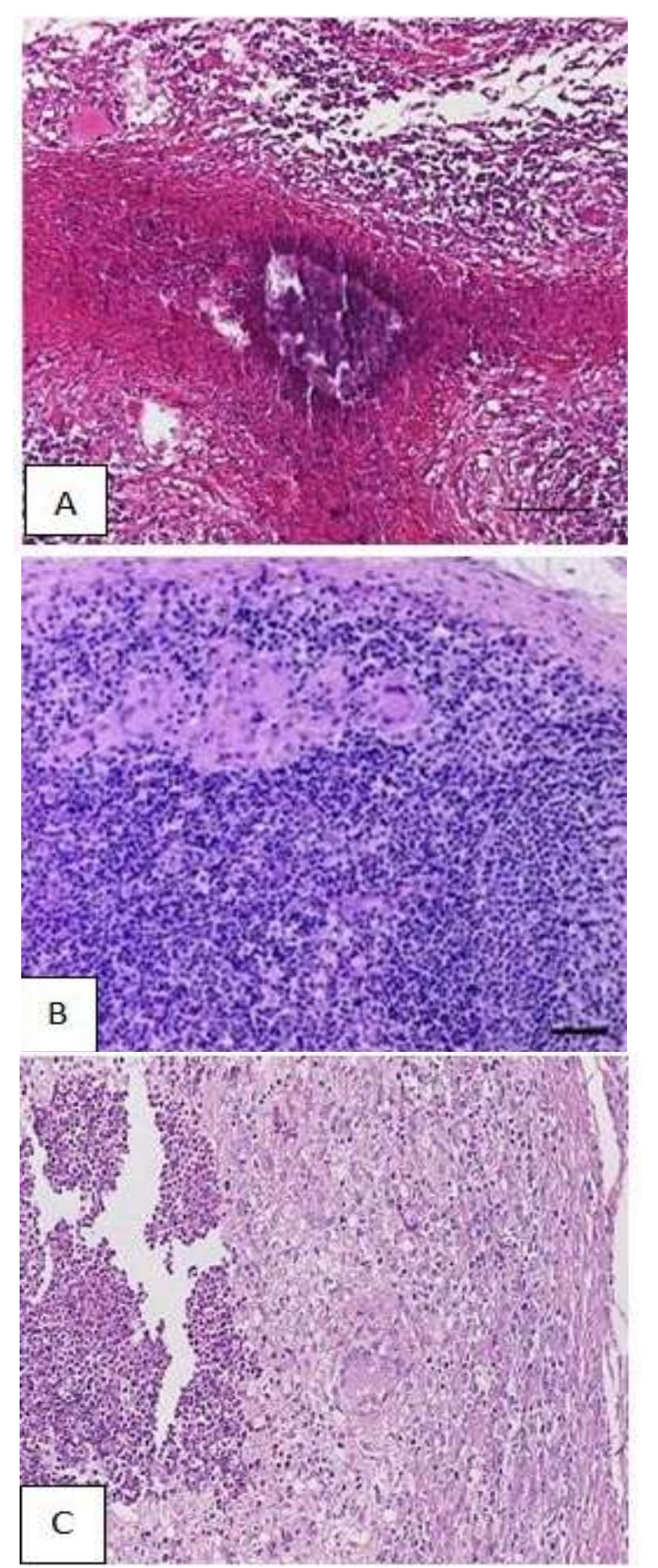

Fig.7: (A) Histological section of a bronchial lymph node characterized by caseous necrosis and mineralization, surrounded by multinucleated giant cells and lymphocyte, (B) Diffused lepromatous granuloma reaction (C)Ulcerative-granulomatous with pyaemic foci bounded by epitheliod and giant cells.

\section{Epidemiology and Transmission:}

JD is prevalent in New Zealand and south-eastern states of Australia dairy cattle and recently impression on the Australian cattle industries recognized generally though ordinary cattle and sheep infected attendant cross- infections have been testified in strains of $M$ paratuberculosis (Perez et al., 1996).

The transmission of Map depended on bacterial ability to survive within the environment, (Eppleston et al., 2014) recounted existence Type $C$ Map strain wasn 't impacted by position but Type $\mathrm{S}$ strain hazard death was 2.3 times greater at dry neighborhood situates comparative with Australia heating place. The capacity to spore-like kinds formation mark it warmth resilient and facilitated escape within environs (Lamont $\boldsymbol{e t}$ al., 2012).

Evidence existence of diverse strain of Map in top soil, water, grass and manure of substantial significance for decline diffusion and exploration, as well as animal activities, farming carry out and of virulence influencing of strain on geographical distribution of these strains. Currently, whole genome sequencing show slight evidence for geographically distinct strains (Ahlstrom $\boldsymbol{e t}$ al., 2014).

MAP is predominantly spread by the fecal-oral way when shed in huge quantities of organisms in the feces and intermittent in early stage of disease because it and upsurges in case of progresses disease and when infected animals are subjected to stress (Sweeney, 2011); virtual easiness of orally experimented transmission in young cattle and sheep.

The offspring of cattle can be born infected if dam in advanced phase of disease because it can shed MAP to variable grades in milk colostrum fecal contaminated of udder housed in polluted pens, and bacterial sums high during the first 2 months of the lactation for that the colostrum from infected cows is abundant risk for spreading of JD to Calves (Nielsen et al., 2008). The repetition of feeding collective colostrum or wasted milk spreading the infection to many calves during susceptible period of life, MAP may noticed in semen, saliva and milk (Slana et al., 2008). Calves greatest risk when exposure to the feces of adults infected with disease and transmitted the organism on fomites, other animals via aerosol unclean dust, the pathogen does not multiply outside a living host (Sweeney et al., 1992b).

Cross-species have role in transmission, outbreaks and maintaining infection cycles of JD, even before molecular strain typing which have great improved knowledge about cross-species transmission of Map was accessible, epidemiologic indication suggest that natural communication between cattle and sheep was rare because cattle and sheep harbor diverse strains were host modified, the simplicity of separating Map from cattle \& uneasy from sheep additional to existence of different strains evidence that milder sickness marked when sheep strains are pass on to cattle (Fridriksdottir et al., 2000). 


\section{Control:}

Because the economic losses in both dairy and beef cattle caused by paratuberculosis disease (Windso, 2014). It must control its depended on population-level measures, applying hygienic measurment and vaccination (Konboon et al., 2018). Another risk factor outline of livestock in farm (Kirkeby et al., 2017). Losses of dairy farmer consist of before, during or after culling (McAloon et al.,2016), In beef cattle the losses be determined by farmer market (Webb Ware et al., 2012), also killing rate of infection summarized (Kudahl et al., 2009).

The control programs have variable aims from lessening of clinical cases and/or MAP incidence (Weber et al., 2018), to remove MAP from herd also limited transmitted of MAP by inducing farm biosecurity through rearing of young stock (Donat $\boldsymbol{e t}$ al., 2017). The main strategy in dairy cattle is prevent calves interaction the feces of adult cows to improve calving area hygiene drawn-out to all managing regions to upturn successful (Ferrouillet et al., 2009) and management of colostrum/milk feeding (Dore $\boldsymbol{e t}$ al., 2012). The most effective control strategy involves 'test-and-cull' which increased biosecurity of farm (Smith et al., 2017).

Both healthy and 'test-and-cull' were essential to become stable the herd station, reduction of calf experience are most effective measure, followed by test occurrence (Camanes et al., 2018). Culling the progeny which infested cows considered as portion of the control strategy rate of in utero infection (Whittington et al., 2009). Pasture and grazing manage utilizing to lessor exposure of extensive grazed livestock (Eppleston et al., 2014).

Even nonappearance linked between MAP and human disease (Groenendaal et al., 2008). The zoonotic potential of $M$. paratuberculosis cannot be ignored, due to vital knowledge gaps in considerate its starring role of human disease (Waddell et al., 2016), its influence on communal healthiness do not measured or described (Waddell et al., 2016).

Immunization of ruminants revealed limitted of disease by decreased of clinical frequency and decreasing faecal shed of MAP (et al.,201470) but it isn't commonly used in cattle because threat interfering with ID testing for bovine tuberculosis (Bastida et al., 2011) . In contrast of Australian, Icelandic and Spanish sheep industries, inoculation widely used (Serrano et al., 2017).

\section{Declaration of competing interest}

On behalf of all authors, I hereby declare that no conflict of interest may interfere with the publication of the manuscript.

\section{REFERENCES}

AHLSTROM C, BARKEMA HW, STEVENSON K, ZADOKS R, BIEK R, KAO R, TREWBY H, HENDRICK S, HAUPSTEIN D, KELTON D, FECTEAU G, LABRECQUE O, MCKENNA S, KEEFE G. AND DEBUCK J., 2014. Phylogenomic analyses elucidate Mycobacterium avium subsp. paratuberculosis diversity at a global, national and provincial scale. In: Proceedings of the Twelfth International Colloquium on Paratuberculosis: 22-26 June 2014. International Association for Paratuberculosis, Parma, p 226.

ALMEIDA S, DORNELES E.M.S, DINIZ C AND ABREU, V., 2017. Quadruplex PCR assay for identification of Corynebacterium pseudotuberculosis differentiating biovar Ovis and Equi. BMC Veterinary Research, 13:290.

ALONSO-HEARN M, PATEL D, DANELISHVILI L, MEUNIER-GODDIK L. AND BERMUDEZ LE., 2008. The Mycobacterium avium subsp. paratuberculosis MAP3464 gene encodes an oxidoreductase involved in invasion of bovine epithelial cells through the activation of host cell Cdc42. Infect Immun 76:170-8. doi:10.1128/ IAI.01913-06.

ASHWANI TIWARI, JOHN A, VANLEEU WEN SHAWN, L.B., MCKENNA GREG P., KEEFE AND HERMAN W., BARKEMA CAN. AND VET J., 2006. Johne's disease in Canada: Part I: Clinical symptoms, pathophysiology, diagnosis, and prevalence in dairy herds, Sep; 47 (9): 874-882.

BANNANTINE JP, BERMUDEZ LE, NO HOLES BARRED., 2013. invasion of the intestinal mucosa by Mycobacterium avium subsp. paratuberculosis. Infect Immun 81:3960-5. doi:10.1128/IAI.00575-13.

BASTIDA F. AND JUSTE RA., 2011. Paratuberculosis control: a review with a focus on vaccination. J Immune Based There Vacines.; 8:9.

BERGHAUS RD, FARVER TB, ANDERSON RJ, JARAVATA CC. AND GARDNER IA., 2006. Environmental sampling for detection of Mycobacterium avium ssp. paratuberculosis on large California dairies. J Dairy Sci.;89 (3):963-70.

BERMUDEZ LE, PETROFSKY M, SOMMER S, BARLETTA RG., 2010. Peyer's patch-deficient mice demonstrate that Mycobacterium avium subsp. paratuberculosis translocates across the mucosal barrier via both $\mathrm{M}$ cells and enterocytes but has inefficient dissemination. Infect Immun 78:3570-7. doi:10.1128/ IAI.01411-09.

CAMANES G, JOLY A, FOURICHON C, BEN ROMDHANE R. AND EZANNO P., 2018. Control measures to prevent the increase of paratuberculosis prevalence in dairy cattle herds: an individual-based modelling approach. Vet Res.;49(1):60.

COELHO A, PINTO M, MIRANDA A, COELHO A, PIRES M. AND MATOS M., 2010. Comparative evaluation of PCR in Ziehl-Neelsen stained smears and 
PCR in tissues for diagnosis of Mycobacterium avium subsp. paratuberculosis.;48:948-50

COUSSENS PM, PUDRITH CB, SKOVGAARD K, REN X, SUCHYTA SP. AND STABEL JR., 2005. Johne's disease in cattle is associated with enhanced expression of genes encoding IL-5, GATA-3, tissue inhibitors of matrix metalloproteinases 1 and 2 , and factors promoting apoptosis in peripheral blood mononuclear cells. Vet Immunol Immunopathol 105:221-34. doi:10.1016/j.vetimm.02.009.

COUSSENS, PM.; SIPKOVSKY, S.; MURPHY, B.; ROUSSEY, J. AND COLVIN, CJ., 2012. Regulatory $\mathrm{T}$ cells in cattle and their potential role in bovine paratuberculosis. Comp Immunol Microbiol Infect Dis 35:233-9. doi:10.1016/j.cimid. 01.004.

DEL-POZO J, GIRLING S, MCLUCKIE J, ABBONDATI E AND STEVENSON K., 2013. An unusual presentation of Mycobacterium avium spp. paratuberculosis infection in a captive tundra reindeer (Rangifer tarandus tarandus). J. Comp. Pathol. 149:126-131.

DHAND NK, EPPLESTON J, WHITTINGTON RJ. AND WINDSOR PA., 2016. Changes in prevalence of ovine paratuberculosis following vaccination with Gudair(R): Results of a longitudinal study conducted over a decade. Vaccine.; 34(42): 5107-13.

DOMINGO M, ENRIC VIDAL AND MARCO A., 2014. Pathology of bovine tuberculosis. Res Vet Sci. 2014 Oct; 97 Suppl:S20-9. doi: 10.1016/j.rvsc.2014.03.017.

DONAT K, HAHN N, EISENBERG T, SCHLEZ K, KÖHLER H, WOLTER W, ROHDE M, PÜTZSCHEL R, RÖSLER U. AND FAILING K., 2016. Within-herd prevalence thresholds for the detection of Mycobacterium avium subspecies paratuberculosis-positive dairy herds using boot swabs and liquid manure samples. Epidemiol Inf.;144(2):413-24.

DONAT, K., 2017. The Thuringian bovine paratuberculosis control programme - results and experiences. Berl Munch Tierarztl Wochenschr. 2017;130 (1-2):42-9.

DORE E, PARE J, COTE G, BUCZINSKI S, LABRECQUE O, ROY JP. AND FECTEAU G., 2012. Risk factors associated with transmission of Mycobacterium avium subsp. paratuberculosis to calves within dairy herd: a systematic review. J. Vet. Intern. Med.; 26 (1):32-45.

EL CHAMY L, LECLERC V, CALDELARI I, REICHHART J.M., 2008. Sensing of 'danger signals' and pathogen-associated molecular patterns defines binary signaling pathways 'upstream' of toll. Nat Immunol 9:1165-70. doi:10.1038/ ni.1643.

ELZO M, RAE D, LANHART S, HEMBRY F, WASDIN J. AND DRIVER J., 2009. Association between cow reproduction and calf growth traits and ELISA scores for paratuberculosis in amulti breed herd of beef cattle. Tropi Anim Health Prod.; 41(6):851-8.

EPPLESTON J, BEGG DJ, DHAND N, WATT B. AND WHITTINGTON RJ., 2014. Environmental survival of Mycobacterium avium subsp. paratuberculosis in different climatic zones of Eastern Australia. Appl Environ Microbiol 80:2337-2342.
EPPLESTON J, BEGG DJ, DHAND N, WATT $B$. AND WHITTINGTON RJ., 2014. Environmental survival of Mycobacterium avium subsp. paratuberculosis in different climatic zones of Eastern Australia. Appl Environ Microbiol 80:2337-2342.

EVERMAN JL, ECKSTEIN TM, ROUSSEY J, COUSSENS P, BANNANTINE JP. AND BERMUDEZ LE., 2015. Characterization of the inflammatory phenotype of Mycobacterium avium subspecies paratuberculosis using a novel cell culture passage model. Microbiology 161:1420-34. doi:10.1099/mic. 0.000106 .

FERROUILLET C, WELLS SJ, HARTMANN WL, GODDEN SM. AND CARRIER J., 2009. Decrease of Johne's disease prevalence and incidence in six Minnesota, USA, dairy cattle herds on a long-term management program.prevVet Med.;88(2):128-37.

FRIDRIKSDOTTIR V, GUNNARSSON E, SIGURDARSON S. AND GUDMUNDSDOTTIR K.B., 2000. Paratuberculosis in Iceland: epidemiology and control measures, past and present, Veterinary Microbiology $77263 \pm 267$.

GARCIA-ISPIERTO I. AND LOPEZ-GATIUS, F., 2016. Early foetal loss correlates positively with seroconversion against Mycobacterium avium paratuberculosis in high-producing dairy cows. Reprod Domest Anim.;51(2):227-31.

GONZALEZ J, GEIJO M V, GARCIA-PARIENTE C, VERNA A, CORPA J M, REYES, L E, FERRERAS MC, JUSTE R A, GARCIA MARIN J F. AND PEREZ V., 2005. Histopathological Classification of Lesions Associated with Natural Paratuberculosis Infection in Cattle, Journal of Comparative Pathology,Vol. 133, pp. 184-196

GONZALEZ J. AND PEREZ V., 2005. Histopathological Classification of Lesions associated with Natural Paratuberculosis Infection in Cattle.Vol.133, Issues2-3, page184-196.

GOVARDHAN RATHNAIAH, DENISE K. ZINNIEL, JOHN P. BANNANTINE, JUDITH R. STABEL, YRJÖ T. GRÖHN, MICHAEL T. COLLINS, RAÚL G. AND BARLETTA., 2017. Pathogenesis, Molecular Genetics, and Genomics of Mycobacterium avium subsp. paratuberculosis, the Etiologic Agent of Johne's Disease, Front Vet Sci.; 4: 187.

GREWAL SK , RAJEEV S, SREEVATSAN S, MICHEL JR FC., 2006. Persistence of Mycobacterium avium subsp. paratuberculosis and other zoonotic pathogens during simulated composting, manure packing and liquid storage of dairy manure. Appl Environ Microbiol 72:565-74.

GROENENDAAL H. AND ZAGMUTT FJ., 2008. Scenario analysis of changes in consumption of dairy products caused by a hypothetical causal link between Mycobacterium avium subspecies paratuberculosis and Cohn's disease. J Dairy Sci.;91(8):3245-58.

GULLIVER E L, PLAIN K M, BEGG D J. AND WHITTINGTON R J., 2015. Histopathological Characterization of Cutaneous Delayed-Type Hypersensitivity and Correlations with Intestinal Pathology and Systemic Immune Responses in Sheep with Paratuberculosis", Journal of Comparative Pathology, Vol. 153, pp. 67-80. 
KALIS CHJ, COLLINS MT, HESSELINK JW. AND BARKEMA HW., 2003. Specificity of two tests for the early diagnosis of bovine paratuberculosis based on cell-mediated immunity: the Johnin skin test and the gamma interferon assay. Vet Microbiol.;97(1):73-86.

KIRKEBY C, GRAESBOLL K, NIELSEN SS, TOFT, N. AND HALASA T., 2017. Epidemiological and economic consequences of purchasing livestock infected with Mycobacterium ovium subsp paratuberculosis.BMC Vet Res.;13(1)202.

KONBOON M, BANI-YAGHOUB M, PITHUA PO, RHEE N. AND ALY SS., 2018. A nested compartmental model to assess the efficacy of paratuberculosis control measures on US dairy farms. PLoS One.;13(10).

KAREN STEVENSON, 2015. Genetic diversity of Mycobacterium avium subspecies Paratuberculosis and the influence of strain type on infection and pathogenesis: a review Veterinary Research volume 46,Article number :64.

KOUL A, HERGET T, KLEBL B. AND ULLRICH A., 2004. Interplay Between Mycobacteria and Host Signaling Pathways",Nature Review, Vol. 2, pp. 189202.

KUDAHL AB. AND NIELSEN SS., 2009. Effect of paratuberculosis on slaughter weight and slaughter value of dairy cows. J Dairy Sci.;92(9):4340-6.

LAMONT EA, BANNANTINE JP, ARMIÉN A, ARIYAKUMAR DS. AND SREEVATSAN S., 2012. Dentification and characterization of a spore-like morphotype in chronically starved Mycobacterium avium subsp. paratuberculosis cultures. PLoS One 7:e30648.

LAMONT EA, O'GRADY SM, DAVIS WC, ECKSTEIN T. AND SREEVATSAN S., 2012. Infection with Mycobacterium avium subsp. paratuberculosis results in rapid interleukin-1beta release and macrophage transepithelial migration. Infect Immun 80:3225-35. doi:10.1128/IAI.06322-11.

LEFRANCOIS LH, PUJOL C, BODIER CC, TEIXEIRA-GOMEZ AP, DROBECQ H. AND ROSSO ML., 2011. Characterization of the Mycobacterium avium subsp. paratuberculosis lamininbinding/histone-like protein ( $\mathrm{Lbp} / \mathrm{Hlp}$ ) which reacts with sera from patients with Crohn's disease. Microbes Infect 13:585-94. doi:10.1016/j.micinf.02.002.

LI RW, LI C. AND GASBARRE LC., 2011. The vitamin $\mathrm{D}$ receptor and inducible nitric oxide synthase associated pathways in acquired resistance to Cooperia oncophora infection in cattle. Vet Res 42:48. doi:10.1186/1297-9716- 42-48 47. Khalifeh MS, AlMajali AM, Stabel JR. Role of nitric oxide production in dairy cows naturally infected with Mycobacterium avium subsp. paratuberculosis. Vet Immunol Immunopathol (2009) 131:97-104. doi:10.1016/j. vetimm.2009.03.020

LUGTON, I., 1999. Mucosa-associated lymphoid tissues as sites for uptake, carriage and excretion of tubercle bacilli and other pathogenic mycobacteria. Immunol Cell Biol 77:364-72. doi:10.1046/j.14401711.1999.00836.x.

MCALOON CG, WHYTE P, MORE SJ, GREEN MJ, O'GRADY L, GARCIA A. AND DOHERTY ML.,
2016. The effect of paratuberculosis on milk yield-- A systematic review and meta-analysis. J Dairy Sci.99(2):1449-60.

MCALOON CG, WHYTE P, MORE SJ, GREEN MJ, O'GRADY L, GARCIA A. AND DOHERTY ML. 2016. The effect of paratuberculosis on milk yield - a systematic review and meta-analysis. J Dairy Sci.;99 (2):1449-60.

NADINE A. EL-SEBAY, MARWAH M. MOHAMED, ELHAM F. EL-SERGANY, ASHRAF M. ABBAS, ROUKAYA M. OSMAN, AND DALIA A. M. ABD EL-MOATY, 2021. Genetic Characterization of Corynebacterium Pseudotuberculosis Isolates in Egypt. Journal of Applied Veterinary Sciences, 6 (2): 15 - 21. doi.org/10.21608/javs.2021.154576

NASR, E.A; SALEEB, O.R.; ABDEL RAHMAN, M.; SHEREEN, A. M.; AND MARWAH, M., 2019. Prevalence Of Bovine Tuberculosis In Different Cattle Breeds In Dairy Farm In Egypt. Journal of Applied Veterinary Sciences, 4(2): 45-51. DOI https://dx.doi.org/10.21608/javs.2019.62656

NIELSEN S.S, BIERRE H. AND TOFT N., 2008. Colostrum and milk as risk factors lor infection with Mycobacterium avium subsp' paratuberculosrs in dairy calle Journat of Dairy Science 91'461 0-461 5.

PEREZ V, GARCIA MARIN JF. AND BADIOLA JJ., 1996. Description and classification of different types of lesion associated with natural paratuberculosis infection in sheep. J Comp Pathol; 114: 107-122.

ROY GL, DE BJ, WOLF R, MORTIER RA, ORSEL K. AND BARKEMA HW. 2017. Experimental infection with Mycobacterium avium subspecies paratuberculosis resulting in decreased body weight in Holstein-Friesian calves. Can Vet J.;58(3):296-8.

SANTMAN-BERENDS IMGA, DE BONTSMOLENAARS AJG, ROOS L, VELTHUIS AGJ. AND VAN SG., 2018 Using routinely collected data to evaluate risk factors for mortality of veal calves. Prev Vet Med.;157:86-93.

SECOTT TE, LIN TL. AND WU CC., 2002. Fibronectin attachment protein is necessary for efficient attachment and invasion of epithelial cells by Mycobacterium avium subsp. paratuberculosis. Infect Immun 70:2670 5. doi:10.1128/ IAI.70.5.2670-2675.

SERRANO M, ELGUEZABAL N, SEVILLA IA, GEIJO MV, MOLINA E, ARRAZURIA R, URKITZA A, JONES GJ, VORDERMEIER M. AND GARRIDO JM., 2017. Tuberculosis detection in paratuberculosis vaccinated calves: new alternatives against interference. PLoS One.;12(1):e0169735.

SLANA I, PAOLICCHI F. AND JANSTOVA B., 2008. Detection methods for Mycobacterium avium subsp paratuberculosis in milk and milk products: a review. Vet Med-Czech 53:283-306.

SMITH RL, AL-MAMUN MA. AND GROHN YT., 2017. Economic consequences of paratuberculosis control in dairy cattle: a stochastic modeling study. Prev Vet Med.;138:17-27.

STABEL, JR., 2000. Transitions in immune responses to Mycobacterium paratu-berculosis. Vet Microbiol 77:465-73. doi:10.1016/S0378-1135(00) 00331-X.

STEVENSON K, HUGHES VM, DE JUAN L, INGLIS NF, WRIGHT F. AND SHARP JM., 2002. 
Molecular characterization of pigmented and nonpigmented isolates of Mycobacterium avium subspecies paratuberculosis. J Clin Microbiol 40:1798-1804.

SWEENEY R.W, WHITLOCK R'H', ROSENBERGER' N.I. (RSGZO) 1992b. Mycobacterium paratuberculosis cultured from milk and supramammary lymph nodes oJ infected asymptomatic cattle' Journal of Clinical Microbiology 30, 1 66-171.

SWEENEY, RW. 2011. Pathogenesis of paratuberculosis. Vet Clin Food Anim 27:537-46.

SWEENEY, R W., 2011. Pathogenesis of Paratuberculosis", Veterinary Clinics of North America: Food and Animal Practice,Vol. 27, pp. 537546.

TEJEDOR JUNCO M.T., LUPIOLA P, SCHULZ U AND GUTIERREZ C., 2008. Isolation of nitrate reductase positive Corynebacterium pseudotuberculosis from dromedary camels. Trop Anim Health Prod., 40:165-7.

TOOKER BC, BURTON JL. AND COUSSENS PM., 2002. Survival tactics of $M$. paratuberculosis in bovine macrophage cells. Vet Immunol Immunopathol 87:429-37. doi:10.1016/S0165-2427(02)00065-X.

WADDELL L, RAJIC A, STARK K. AND MCEWEN SA., 2016. Mycobacterium avium ssp. Paratuberculosis detection in animals, food, water and other sources or vehicles of human exposure: a scoping review of the existing evidence. Prev Vet Med.;132:32-48.

WADDELL LA, RAJIĆ A, STÄRK KDC. AND MCEWEN SA., 2016. The potential public health impact of Mycobacterium avium ssp. paratuberculosis: global opinion survey of topic specialists. Zoo Pub Health. ;63(3):212-22.

WEBB WARE JK, LARSEN JWA. AND KLUVER P., 2012. Financial effect of bovine Johne's disease in beef cattle herds in Australia. Aust Vet J.;90(4):11621.

WEBB WARE, JK, LARSEN JWA, KLUVER, P., 2012. Financial effect of bovine Johne's disease in beef cattle herds in Australia. Aust Vet J.;90(4):116-21.

WEBER M, AALBERTS M, DIJKSTRA T. AND DE ROO A., 2018. Results of milk quality assurance programme for paratuberculosis in Dutch dairy herds indicate reduced transmission of the infection. Bull Int Dairy Fed.;493:23-34.

WEBER MF, VERHOEFF J, VAN SCHAIK G. AND VAN MAANEN C. 2009. Evaluation of ZiehlNeelsen stained faecal smear and ELISA as tools for surveillance of clinical paratuberculosis in cattle in the Netherlands. Prev Vet Med.;92(3):256-66.

WEISS D J. AND SOUZA C D., 2008. Review Paper: Modulation of Mononuclear Phagocyte Function by Mycobacterium avium subsp. Paratuberculosis", Veterinary Pathology, Vol. 45, pp. 829-841.

WEISS DJ, EVANSON OA, MCCLENAHAN DJ, ABRAHAMSEN MS. ANDWALCHECK BK., 2001. Regulation of expression of major histocompatibility antigens by bovine macrophages infected with Mycobacterium avium subsp. paratuberculosis or Mycobacterium avium subsp. avium. Infect Immun 69:1002-8.

doi:10.1128/IAI.69.2.1002-1008.

WHITLOCK R, ROSENBERGER A. AND SWEENEY

R., 1996. Distribution of $M$ paratuberculosis in tissues of cattle form herds infected with Johne's disease. In: Chiodini R, Hines M, Collins M, editors. Proceedings of the 5th international colloquium on Paratuberculosis, Maddison, USA 29 September - 4 October. Rehoboth: International Association for Paratuberculosis;. p. 168-74.

WHITTINGTON R. AND WINDSOR P., 2009. In utero infection of cattle with Mycobacterium avium subsp. paratuberculosis: a critical review and meta-analysis. Vet J.;179(1):60-9.

WHITTINGTON R.J, TARAGEL C.A, MARSH I, OTTAWAY S, SEAMAN J. AND FRIDRIKSDOTTIR V., 2001. Molecular epidemiological confirmation and circumstances of occurrence of sheep (S) strains of Mycobacterium avium subsp. paratuberculosis in cases of paratuberculosis in cattle in Australia and sheep and cattle in IcelandVeterinary Microbiology, Volume 79, Issue 4, 19 April, Pages 311-322

WINDSOR PA. AND WHITTINGTON RJ. 2010., Evidence for age susceptibility of cattle to Johne's disease. Vet J 184:37-44. doi:10.1016/j.tvj1.2009.01.007.

WINDSOR, PA., 2014. Managing control programs for ovine caseous lymphadenitis and paratuberculosis in Australia, and the need for persistent vaccination. Vet Med Res Rep.;5:11-22.

YERUHAM I, FRIEDMAN S, SAMUEL PERL AND DANIEL ELAD., 2003. Corynebacterium pseudotuberculosis infection in Israeli dairy cattle, 131(2):947-55.

ZHAO B, COLLINS MT. AND CZUPRYNSKI C.J., 1997. Effects of gamma interferon and nitric oxide on the interaction of Mycobacterium avium subsp. paratuberculosis with bovine monocytes. Infect Immun 65:1761-6.

How to cite this article:

S.A. Radam; I.B. Falih; S.L. Hassan and H.B. ALSabaawy, 2021. Pathological Impact of Johne's disease in Cattle: A Review Article. Journal of Applied Veterinary Sciences, 6 (3): $38-47$.

DOI: https://dx.doi.org/10.21608/javs.2021.76316.1080 